P-ISSN 2722-2101, E-ISSN 2722-4201

Loyalitas Kreativitas

Program Studi Ekonomi Manajemen Universitas Pamulang

Aldi Masyarakat Kreatif

Jurnal LOKABMAS Kreatif Vol.02,No.03.Nov 2021

Hal.109-118

Email:jurnalkreatif.manajemen@gmail.com

\title{
PENGENALAN AKUNTANSI DASAR PADA UMKM ROTI EYANG GUNA MENINGKATKAN SUSTAINABILITY
}

\author{
Putri Nurmalasari, S.E., M.Si ${ }^{1}$, Akhmad Sigit Adiwibowo, S.E., M.Ak ${ }^{2}$, \\ Fina Ratnasari, S.E., M.Ak ${ }^{3}$
}

Dosen Ekonomi Fakultas Ekonomi Akutansi Universitas Pamulang

Email dosen@unpam.ac.id, dosen@unpam.ac.id, dosen02630@unpam.ac.id

\begin{abstract}
ABSTRAK
Pengabdian kepada masyarakat (PKM) ini bekerjasama dengan UMKM Roti Eyang yang berlokasi di jakarta. Tujuan dari PKM ini adalah untuk memberikan pembimbingan dan gambaran terntang pembuatan laporan keuangan kepada pemilik UMKM Roti Eyang bapak Suharso, karena pemilik UMKM Roti Eyang sangat antusias ingin mengetahui dasar-dasar akuntansi sehingga bisa membuat laporan keuangan sendiri.

Kegiatan PKM ini dilaksanakan pada hari Sabtu, 24 April 2021 via zoom meet yang dihadiri oleh lima peserta, yaitu dari Universitas Pamulang dihadiri oleh tim dosen akuntansi, Putri Nurmala, S.E., M.Si., Akhmad Sigit Adiwibowo, S.E., M.Ak., dan Fina Ratnasari, S.E., M.Ak., selain itu dihadiri pula oleh dosen akuntansi ITB Swadharma, Rita, S.E., M.Ak.., dari UMKM Roti Eyang diwakili oleh pemiliknya, yaitu Bapak Suharso Sulistyo.

Tujuan dari Kegiatan Pengabdian Kepada Masyarakat adalah untuk melaksanakan salah satu Tri Darma Perguruan Tinggi. Selain itu diharapkan dengan pengabdian kepada masyarakat tersebut keberadaan perguruan tinggi dapat memberikan kontribusi besar kepada pengembangan dan penerapan keilmuan kepada masyarakat.
\end{abstract}

Kata Kunci: Sustainability, UMKM, Laporan Keuangan

\begin{abstract}
This Community Service (PKM) is in collaboration with the Roti Eyang UMKM which is located in Jakarta. The purpose of this PKM is to provide guidance and an overview of the preparation of financial reports to the owners of the Roti Grandparents SMEs, Mr. Suharso, because the owners of the Grandparents Roti SMEs are very enthusiastic about knowing the basics of accounting so that they can make their own financial reports.

This PKM activity was held on Saturday, April 24, 2021 via zoom meet which was attended by five participants, namely from Pamulang University attended by a team of accounting lecturers, Putri Nurmala, SE, M.Sc., Akhmad Sigit Adiwibowo, SE, M.Ak. , and Fina Ratnasari, SE, M.Ak., in addition to that, the ITB accounting lecturer Swadharma, Rita, SE, M.Ak.., from MSME Roti Eyang was represented by the owner, namely Mr. Suharso Sulistyo.

The purpose of Community Service Activities is to carry out one of the Tri Dharma of Higher Education. In addition, it is hoped that with community service, the existence of universities can make a major contribution to the development and application of science to the community.
\end{abstract}

Keywords: Financial Report, UMKM, Sustainbility 
Loyalitas Kreativitas Aldi Masyarakat Kreatif
P-ISSN 2722-2101, E-ISSN 2722-4201

Program Studi Ekonomi Manajemen Universitas Pamulang Jurnal LOKABMAS Kreatif Vol.02,No.03.Nov 2021

Hal.109-118

Email:jurnalkreatif.manajemen@gmail.com

\section{PENDAHULUAN}

Kinerja UKM menunjukan adanya peningkatan dalam beberapa tahun terakhir. Hal tersebut dapat dilihat pada besaran Produk Domestik Bruto (PDB) yang dihasilkan oleh aktivitas UKM yang dicatat oleh BPS dari tahun 2003-2007, jumlah UKM pada tahun 2003-2006 dan 2007 berturut-turut mencapai 52,10\%; 52,35\%; $53,16 \%$; dan $53,40 \%$ dari total unit usaha di Indonesia dan menyerap 99,4\% dari total angkatan kerja yang bekerja sama dengan kontribusi terhadap Produk Domestik Regional Bruto (PDRB) sebesar 52,89\%. Kemudian BPS menunjukkan besaran PDB di tahun 2008 mencapai nilai $\mathrm{Rp}$ 1.013,5 triliun (56,7 persen dari PDB). Jumlah unit usaha UKM pada tahun 2008 mencapai 42,4 juta, sedangkan jumlah tenaga kerja yang bekerja di sektor ini tercatat 79 juta pekerja. Bahkan menurut Purnomo Setyawan (2009), pertumbuhan PDB UKM periode 2005-2008 ternyata lebih tinggi daripada total PDB, yang sumbangan pertumbuhannya lebih besar dibandingkan dengan Usaha Besar (Setyawan, 2009).

Permasalahan yang biasanya banyak dihadapi oleh perusahaan kecil dan menengah antara lain dalam bidang pemasaran, keuangan, dan manajemen (Dodge dan John, Xueli dan Allan, 1999; Barbara, et al, 2000). Hal tersebut juga dinyatakan oleh Tambunan (2000), bahwa masalah lemahnya manajemen, pemasaran, kekurangan pembiayaan, kekurangan keterampilan, kekurangan bahan baku, serta kelemahan dalam penyerapan tekonologi merupakan faktor penghambat pengembangan UKM. Permasalahan lain juga diungkap dalam penelitian yang dilakukan oleh Mall dan Bala (1988), Theng dan Jasmine (1996), menunjukkan bahwa penyebab kegagalan UKM berasal dari faktor-faktor luar perusahaan yang tidak dapat dikendalikan oleh manajemen, dan juga faktor dari dalam perusahaan itu sendiri antara lain personality, financial, dan operational short coming (Theng dan Jasmine, 1996). UKM menghadapi permasalahan dalam bidang pemasaran produk, teknologi, permodalan, kualitas sumber daya manusia, persaingan usaha yang ketat, kurangnya teknis produksi dan keahlian dan masalah manajemen termasuk didalamnya pengelolaan keuangan dan akuntansi.

Dari permasalahan-permasalahan tersebut, dapat diambil suatu benang merah bahwa sebetulnya usaha-usaha kecil memiliki karakter permasalahan yang sama. Hal tersebut dikarenakan perusahaan tidak memiliki cukup informasi, baik informasi dari dalam ataupun luar usaha. Salah satu sistem yang dapat menyediakan informasi yang dibutuhkan oleh suatu perusahaan adalah sistem informasi akuntansi. Kurangnya informasi akuntansi dalam suatu perusahaan dapat membahayakan kelangsungan usaha kecil.

Belkaoui (2000) mendefinisikan informasi akuntansi sebagai informasi kuantitatif tentang entitas ekonomi yang bermanfaat untuk pengambilan keputusan ekonomi dalam menentukan pilihan-pilihan diantara alternatif-alternatif tindakan. Informasi akuntansi meliputi informasi kuantitatif tentang informasi kekayaan entitas, likuiditas, informasi yang berkenaan dengan distribusi nilai tambah di antara stake holder, dan sejumlah besar informasi berhubungan dengan ekonomi dalam perusahaan (Staubus, 1985). Penelitian Arnold dan Hope (1990), menyatakan bahwa pada dasarnya informasi akuntansi bersifat keuangan dan terutama digunakan untuk tujuan pengambilan keputusan, pengawasan, dan implementasi keputusankeputusan tersebut. Penggunaan informasi akuntansi itu untuk perencanaan strategis, pengawasan manajemen, dan pengawasan operasional (Anthony, 1965; Simons, 1991). Selain itu informasi akuntansi juga berguna dalam rangka menyusun berbagai proyeksi, misalnya proyeksi kebutuhan uang kas di masa yang akan datang, mengontrol biaya, mengukur dan meningkatkan produktivitas dan memberikan dukungan terhadap proses produksi (Johnson dan Kaplan, 1987).

\section{B. GAMBARAN UMUM SITUASI}

Roti Eyang yang dimiliki oleh bapak Suharso sudah mulai beroperasi sejak oktober 2007. Hasil survey dan wawancara dengan bapak Suharso, terlihat bahwa beliau sangat antusias ingin dapat membuat laporan keuangan sendiri. Di karenakan sejak 
Loyalitas Kreativitas Aldi Masyarakat Kreatif
P-ISSN 2722-2101, E-ISSN 2722-4201

Program Studi Ekonomi Manajemen Universitas Pamulang Jurnal LOKABMAS Kreatif Vol.02,No.03.Nov 2021

Hal.109-118

Email:jurnalkreatif.manajemen@gmail.com beroprasional bapak Suharso hanya mencatat penjualan secara administrasinya saja dan tidak membuat laporan keuangan. Dalam beberapa tahun terakhir menurut penjelasan beliau, beliau menggunakan jasa temannya untuk membuatkan laporan keuangan untuk pelaporan pajak tanpa tahu cara membuatnya dan tanpa mengetahui filosofi dari setiap komponen-komponen laporan keuangan.

\section{RUMUSAN MASALAH}

Berdasarkan analisis situasi permasalahan tersebut, maka rumusan masalah dalam pengabdian kepada masyarakat ini adalah sebagai berikut :

1. Bagaimana memberikan kemudahan dalam pembuatan laporan keuangan pada pelaku UMKM Roti Eyang.

2. Bagaimana memberikan informasi dalam pembuatan laporan keuangan untuk meningkatkan Sustainability agar bisa diterapkan pelaku UMKM Roti Eyang.

\section{TUJUAN PELAKSANAAN}

Adapun tujuan dari kegiatan Pengabdian

Kepada Masyarakat adalah:

1. Untuk memberikan kemudahan dalam pembuatan laporan keuangan pada pelaku UMKM Roti Eyang.

2. Untuk memberikan informasi dalam pembuatan laporan keuangan untuk meningkatkan Sustainability agar bisa diterapkan pelaku UMKM Roti Eyang.

\section{TINJAUAN PUSTAKA UMKM}

UMKM merupakan suatu usaha yang hanya memiliki ruang lingkup pasar yang kecil, tenaga kerja yang sedikit, dan dikelola sendiri oleh pemilik usaha (Simmons, Armstrong \& Durkin, 2008). Dalam Undang-Undang Republik Indonesia Nomor 20 Tahun 2008 tentang Usaha Mikro, Kecil, dan Menengah membagi UMKM menjadi beberapa kriteria, yaitu:

1.Kriteria Usaha Mikro adalah sebagai berikut:

a. Memiliki kekayaan bersih paling banyak Rp 50.000.000,00 (lima puluh juta rupiah) tidak termasuk tanah dan bangunan tempat usaha; atau

b. Memiliki hasil penjualan tahunan paling banyak Rp 300.000.000,00 (tiga ratus juta rupiah).

2. Kriteria Usaha Kecil adalah sebagai berikut:

a. Memiliki kekayaan bersih lebih dari Rp 50.000.000,00 (lima puluh juta rupiah) sampai dengan paling banyak Rp 500.000.000,00 (lima ratus juta rupiah) tidak termasuk tanah dan bangunan tempat usaha; atau

b. Memiliki hasil penjualan tahunan lebih dari Rp 300.000.000,00 (tiga ratus juta rupiah) sampai dengan paling banyak Rp 2.500.000.000,00 (dua milyar lima ratus juta rupiah).

3. Kriteria Usaha Menengah adalah sebagai berikut:

a. Memiliki kekayaan bersih lebih dari Rp 500.000.000,00 (lima ratus juta rupiah) sampai dengan paling banyak $\mathrm{Rp} \quad 10.000 .000 .000,00$ (sepuluh milyar rupiah) tidak termasuk tanah dan bangunan tempat usaha; atau

b. Memiliki hasil penjualan tahunan lebih dari Rp 2.500.000.000,00 (dua milyar lima ratus juta rupiah) sampai dengan paling banyak Rp50.000.000.000,00 (lima puluh milyar rupiah).

\section{Laporan Keuangan}

Menurut Harahap (2013:105)

laporan keuangan menggambarkan kondisi keuangan dan hasil usaha suatu perusahaan pada saat tertentu atau jangka waktu tertentu. Adapun jenis laporan keuangan yang lazim dikenal adalah neraca, laporan laba rugi, atau hasil usaha, laporan arus kas, laporan perubahan posisi keuangan. Menurut Standar Akuntansi Keuangan (2009:1), laporan Keuangan merupakan bagian dari proses pelaporan keuangan.Laporan keuangan yang lengkap biasanya meliputi neraca, laporan laba rugi, laporan perubahan posisi keuangan ( yang dapat disajikan dalam berbagai cara, seperti sebagian laporan arus kas dana), 
Loyalitas Kreativitas Aldi Masyarakat Kreatif
P-ISSN 2722-2101, E-ISSN 2722-4201

Program Studi Ekonomi Manajemen Universitas Pamulang Jurnal LOKABMAS Kreatif Vol.02,No.03.Nov 2021

Hal.109-118

Email:jurnalkreatif.manajemen@gmail.com catatan dan laporan lain, serta materi penjelasan yang merupakan bagian integral dari laporan keuangan.

Menurut Munawir (2010:5), pada umumnya laporan keuangan itu terdiri dari neraca dan perhitungan laba rugi serta laporan perubahan ekuitas. Neraca menunjukkan/menggambarkan jumlah aset , kewajiban dan ekuitas dari suatu perusahaan pada tanggal tertentu. Sedangkan perhitungan (laporan ) laba-rugi memperlihatkan hasilhasil yang telah dicapai oleh perusahaan serta beban yang terjadi selama periode tertentu, dan laporan perubahan ekuitas menunjukkan sumber dan penggunaan atau alasan-alasan yang menyebabkan perubahan ekuitas perusahaan. Mulai tahun 1994 IAI, melalui Pernyataan Standar Akuntansi Keuangan (PSAK) nomor 2 (para. 04) menentukan, bahwa laporan perubahan posisi keuangan tidak boleh lagi disajikan sebagai laporan arus dana, tetapi harus berupa laporan arus kas. Sebagai alasan perubahan tersebut disebutkan bahwa informasi arus kas historis berguna untuk: (1) menunjukkan jumlah, waktu, dan kepastian arus kas masa depan, dan (2) meneliti kecermatan taksiran arus kas masa depan. Laporan keuangan yang lengkap biasanya meliputi :

- Laporan posisi keuangan

- Laporan laba rugi komprehensif

- Laporan perubahan ekuitas

- Laporan arus kas

- Catatan atas laporan keuangan Unsur yang berkaitan secara langsung dengan pengukuran posisi keuangan adalah aset, kewajiban,dan ekuitas. Sedangkan unsur yang berkaitan dengan pengukuran kinereja dalam laporan laba rugi adalah penghasilan dan beban. Laporan posisi keuangan biasanya mencerminkan berbagai unsur laporan laba rugi dan perubahan dalam berbagai unsur neraca.

\section{Aset}

Aset seperti properti dan barang berharga merupakan sumber ekonomi yang dimiliki individu atau perusahaan karena biasanya bisa digunakan untuk pembayaran. Aset merupakan benda yang mudah diubah menjadi tunai. Aset yang dimiliki perusahaan dicatat dalam laporan keuangan dalam nilai keuangan.

Menurut Warren, et all (2015:493) Aset tetap (fixed asset) adalah aset yang bersifat jangka panjang atau secara relatif memiliki sifat permanen seperti peralatan, mesin, gedung, dan tanah. Menurut Standar Akuntansi Keuangan Aset tetap adalah aset berwujud yang :

1. Dimiliki utuk digunakan dalam produksi atau peyediaan barang atau jasa, untuk tujuan adminstratif; dan

2. Diharapkan untuk digunakan selama dari satu periode.

Menurut Rudianto (2009:276) Aset tetap merupakan barang berwujud milik perusahaan yang sifatnya relatif permanen dan digunakan dalam kegiatan normal perusahaan bukan untuk diperjualbelikan. Berdasarkan beberapa pengertian diatas maka dapat disimpulkan bahwa aset tetap merupakan salah satu jenis kekayaan yang dimiliki oleh perusahaan dan dibeli untuk memperlancar oprasional perusahaan bukan untuk dijual.

\section{Utang}

Munawir (2010:18) berpendapat
utang merupakan semua kewajiban keuangan perusahaan kepada pihak lain yang belum terpenuhi, dimana hutang ini merupakan sumber dana atau modal perusahaan yang berasal dari kreditor".

Menurut FASB (Financial Accounting Standart Board) dalam Pithaloka (2009), hutang adalah pengorbanan manfaat ekonomi masa mendatang yang timbul karena kewajiban sekarang suatu entitas untuk menyerahkan aktiva atau memberikan jasa kepada entitas lain dimasa mendatang sebagai akibat transaksi masa lalu.

Achmad Tjahjono (2009:152) mendefinisikan utang sebagai kewajiban suatu perusahaan yang timbul dari transaksi pada waktu yang lalu dan harus dibayar dengan kas,barang atau jasa di masa yang akan datang. Berdasarkan pengertian diatas utang atau sering disebut juga sebagai kewajiban, dalam pengertian sederhana dapat diartikan sebagai kewajiban keuangan yang harus dibayar oleh perusahaan kepada pihak lain. 


\section{Loyalitas Kreativitas Aldi Masyarakat Kreatif}

P-ISSN 2722-2101, E-ISSN 2722-4201

Program Studi Ekonomi Manajemen Universitas Pamulang Jurnal LOKABMAS Kreatif Vol.02,No.03.Nov 2021

Hal.109-118

Email:jurnalkreatif.manajemen@gmail.com

\section{Modal}

Modal adalah dana yang digunakan untuk membiayai pengadaan aktiva dan operasi perusahaan. Modal terdiri dari itemitem yang ada disisi kanan suatu neraca, yaitu hutang, saham biasa, saham preferen dan laba ditahan. Sedangkan modal terdiri dari modal sendiri dan modal asing. Perimbangan antara seluruh modal asing dan modal sendiri disebut struktur keuangan, dan perimbangan antara modal asing dan modal sendiri yang bersifat jangka panjang akan membentuk sruktur permodalan (Atmaja, 2008).

Menurut Atmaja (2008) jenis-jenis modal dibagi menjadi beberapa bagian, yaitu:
a. Biaya Hutang (cost of debt)
b. Biaya Saham Preferen
c. Biaya Laba ditahan
d. Biaya saham biasa.

\section{Pendapatan}

Pendapatan berpengaruh sangat besar bagi keseluruhan hidup perusahaan, semakin besar pendapatan yang diperoleh perushaan maka semakin besar kemampuan perusahaan untuk membiayai pengeluaran perusahaan. Pendapatan merupakan salah satu unsur yang paling utama dalam pembentukan laporan laba rugi perusahaan

Soekartawi (2012:132) menjelaskan pendapatan akan mempengaruhi banyaknya barang yang dikonsumsikan, bahwa sering kali dijumpai dengan bertambahnya pendapatan, maka barang yang dikonsumsi bukan saja bertambah, tapi juga kualitas barang tersebut ikut menjadi perhatian. Misalnya sebelum adanya penambahan pendapatan beras yang dikonsumsikan adalah kualitas yang kurang baik, akan tetapi setelah adanya penambahan pendapatan maka konsumsi beras menjadi kualitas yang lebih baik.

Menurut Kusnadi (2000 : 19) menyatakan bahwa pendapatan dapat diklasifikasikan menjadi dua bagian, yaitu :

1. Pendapatan Operasional adalsah pendapatan yang timbul dari penjualan barang dagangan, produk atau jasa dalam periode tertentu dalam rangka kegiatan utama atau yang menjadi tujuan utama perusahaan yang berhubungan langsung dengan usaha (operasi) pokok perusahaan yang bersangkutan. Pendapatan ini sifatnya normal sesuai dengan tujuan dan usaha perusahaan dan terjadinya berulang - ulang selama perusahaan melangsungkan kegiatannya. Pendapatan operasional untuk setiap perusahaan berbeda-beda sesuai dengan jenis usaha yang dikelola perusahaan. Salah satu jenis pendapatan operasional perusahaan adalah pendapatan yang bersumber dari penjualan. Penjualan ini berupa penjualan barang dan penjualan jasa yang menjadi objek maupun sasaran utama dari usaha pokok perusahaan. Pendapatan operasional dapat diperoleh dari dua sumber yaitu:

a. Penjualan kotor yaitu merupakan semua hasil atau penjualan barang-barang maupun jasa sebelum dikurangi dengan berbagai potongan-potongan atau pengurangan lainnya untuk dibebankan kepada langganan atau yang membutuhkannya.

b. Penjualan bersih yaitu merupakan hasil penjualan yang sudah diperhitungkan atau dikurangkan dengan berbagai potonganpotongan yang menjadi hak pihak pembeli. Jenis pendapatan operasional timbul dari berbagai cara, yaitu:

1) Pendapatan yang diperoleh dari kegiatan usaha yang dilaksanakan sendiri oleh perusahaan tersebut.

2) Pendapatan yang diperoleh dari kegiatan usaha dengan adanyahubungan yang telah disetujui, misalnya penjualan konsinyasi.

3) Pendapatan dari kegiatan usaha yang dilaksanakan melalui kerjasamadengan para investor.

2. Pendapatan Non Operasional. Pendapatan yang diperoleh perusahaan dalam periode tertentu, akan tetapi bukan diperoleh dari kegiatan operasional utama perusahaan. Adapun jenis dari pendapatan ini dapat dibedakan sebagai berikut.

a. Pendapatan yang diperoleh dari penggunaan aktiva atau sumber ekonomi perusahaan oleh pihak lain. Contohnya, pendapatan bunga, sewa, royalti dan lainlain. Pendapatan yang diperoleh dari penjualan aktiva diluar barang dagangan atau hasil produksi. Contohnya, penjualan surat-surat berharga, penjualan aktiva tak berwujud. 
Loyalitas Kreativitas Aldi Masyarakat Kreatif
P-ISSN 2722-2101, E-ISSN 2722-4201

Program Studi Ekonomi Manajemen Universitas Pamulang Jurnal LOKABMAS Kreatif Vol.02,No.03.Nov 2021

Hal.109-118

Email:jurnalkreatif.manajemen@gmail.com b. Pendapatan bunga, sewa, royalti, keuntungan (laba), penjualan aktiva tetap, investasi jangka panjang dan dividen merupakan pendapatan diluar usaha bagi perusahaan-perusahaan yang bergerak di bidang manufaktur dan perdagangan. Pendapatan yang diperoleh dari peningkatan ekuitas dari transaksi-transaksi yang bukan kegiatan utama dari entitas dan dari transaksi-transaksi atau kejadian-kejadian lainnya serta keadaan-keadaan yang mempengaruhi entitas selain yang dihasilkan dari investasi pemilik disebut dengan keuntungan.

\section{Biaya}

Menurut Supriyono (2011: 12) mendefinisikan biaya sebagai harga perolehan yang dikorbankan atau digunakan dalam rangka memperoleh penghasilan (revenue) yang akan dipakai sebagai pengurang penghasilan. Sedangkan pengertian biaya menurut Supriyono (2011: 12) adalah harga perolehan yang dikorbankan atau digunakan dalam rangka memperoleh penghasilan (revenue) yang akan dipakai sebagai pengurang penghasilan.

Menurut Mulyadi (2014 : 13), biaya dapat diklasifikasikan ke dalam lima macam penggolongan biaya yaitu:

1. Penggolongan biaya menurut objek pengeluaran

Nama objek pengeluaran merupakan dasar penggolongan biaya. Misalnya objek pengeluaran adalah alat tulis kantor, maka semua pengeluaran yang berhubungan dengannya disebut biaya alat tulis kantor.

2. Penggolongan biaya menurut fungsi pokok dalam perusahaan

Biaya dikelompokan menjadi tiga kelompok berdasarkan fungsi pokok dalam perusahaan yaitu:

a.Biaya Produksi Merupakan biayabiaya yang terjadi untuk mengelolah bahan baku menjadi produk jadi. Contohnya adalah biaya depresiasi mesin, biaya bahan baku, biaya bahan penolong, biaya gaji karyawan yang bekerja dalam bagian-bagian, baik yang langsung maupun tidak langsung berhubungan dengan proses produksi.

b.Biaya Pemasaran Merupakan biaya-biaya yang terjadi untuk melaksanakan kegiatan pemasaran produk. Contohnya biaya iklan, biaya promosi, biaya angkutan dari gudang perusahaan ke gudang pembeli, gaji karyawan bagian yang melaksanakan kegiatan pemasaran.

c.Biaya Administrasi dan Umum Merupakan biaya-biaya untuk mengkoordinasikan kegiatan produksi dan pemasaran produk. Contoh biaya ini adalah biaya gaji karyawan bagian keuangan, akuntansi, personalia dan bagian hubungan masyarakat, biaya pemeriksaan akuntan.

3. Penggolongan biaya menurut hubungan biaya dengan sesuatu yang dibiayai Dapat dikelompokkan menjadi dua golongan, yaitu:

a. Biaya Langsung (Direct Cost)

Biaya yang terjadi, yang penyebab satusatunya adalah karena adanya sesuatu yang dibiayai. Jika sesuatu yang dibiayai tersebut tidak ada, maka biaya langsung tidak akan terjadi. Dengan demikian biaya langsung akan mudah diidentifikasikan dengan sesuatu yang dibiayai. Biaya produksi 'langsung terdiri dari biaya bahan baku dan biaya tenaga kerja langsung. Biaya langsung departemen adalah semua biaya yang terjadi di dalam departemen tertentu. Contohnya adalah biaya tenaga kerja yang bekerja dalam departemen pemeliharaan merupakan biaya langsung departemen bagi departemen pemeliharaan dan 10 biaya depresiasi mesin yang dipakai dalam departemen tersebut, merupakan biaya langsung bagi departemen tersebut.

b. Biaya Tidak Langsung (In Direct Cost)

Biaya yang terjadi tidak hanya disebabkan oleh sesuatu yang dibiayai. Biaya ini tidak dapat dihubungkan secara langsung pada unit yang diproduksi. Biaya ini dalam hubungannya dengan produk disebut dengan istilah biaya produksi tidak langsung atau biaya overhead pabrik. Contohnya biaya gaji akunting, biaya gaji direktur, biaya gaji bagian HRD.

4. Penggolongan biaya menurut perilaku biaya dalam hubungannya dengan perubahan volume kegiatan

Dalam hubungannya dengan perubahan volume kegiatannya, biaya dapat digolongkan menjadi:

a.Biaya Variabel 
Loyalitas Kreativitas Aldi Masyarakat Kreatif
P-ISSN 2722-2101, E-ISSN 2722-4201

Program Studi Ekonomi Manajemen Universitas Pamulang Jurnal LOKABMAS Kreatif Vol.02,No.03.Nov 2021

Hal.109-118

Email:jurnalkreatif.manajemen@gmail.com
Merupakan biaya yang jumlah totalnya berubah sebanding dengan perubahan volume kegiatan. Contohnya biaya bahan baku dan biaya tenaga kerja.

b. Biaya Semi

Variabel Biaya Semi Variabel adalah biaya yang berubah tidak sebanding dengan perubahan volume kegiatan. Biaya ini mengandung unsur biaya tetap dan unsur biaya variabel.

c. Biaya Semi Fixed

Merupakan biaya yang tetap untuk tingkat volume kegiatan tertentu dan berubah dengan jumlah yang konstan pada volume produksi tertentu.

d. Biaya Tetap Merupakan biaya yang jumlah totalnya tetap dalam kisar volume kegiatan tertentu.

5. Penggolongan biaya atas dasar jangka waktu manfaatnya

a. Pengeluaran modal

Pengeluaran modal adalah biaya yang mempunyai manfaat lebih dari satu periode akuntansi. Contoh pengeluaran modal adalah pengeluaran untuk pembelian aktiva tetap, untuk reparasi besar terhadap aktiva tetap, untuk promosi besar-besaran.

b. Pengeluaran pendapatan

Pengeluaran pendapatan adalah biaya yang hanya mempunyai manfaat dalam periode akuntansi terjadinya pengeluaran tersebut. Contoh pengeluaran pendapatan antara lain adalah biaya iklan, biaya telex, dan biaya tenaga kerja.

\section{KERANGKA PEMECAHAN MASALAH}

Hal mendasar yang ditawarkan untuk memecahkan masalah adalah melalui kegiatan pembuatan laporan arus kas kepada pelaku UMKM yang dikemas dengan nama kegiatan "Pengenalan Akuntansi Dasar Pada UMKM Roti Eyang Guna Meningkatkan Sustainability". Untuk lebih jelasnya dapat dilihat dalam skema di bawah ini:

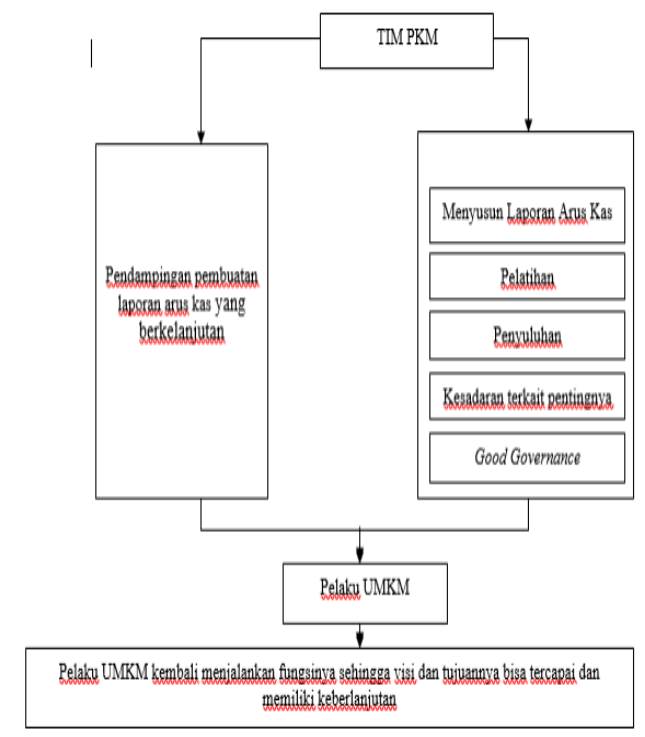

Realisasi sosialisasi pada hari pelaksanaan penyuluhan. Saat pelaksanaan kami akan memberikan materi dan diskusi. Disini kami akan sangat terbuka terkait pertanyaanpertanyaan dari pelaku UMKM Roti Eyang.

Realisasi sosialisasi pada hari pelaksanaan penyuluhan. Saat pelaksanaan kami akan memberikan materi dan diskusi. Disini kami akan sangat terbuka terkait pertanyaan-pertanyaan dari pelaku UMKM Roti Eyang.

Adapun langkah-langkah sosialisasi yang dilakukan oleh tim pelaksana PKM pada saat pelaksanaan penyuluhan adalah sebagai berikut:

1. Pemilik UMKM Roti Eyang akan diberikan penjelasan mengenai konsep dasar akuntansi

2. Pemilik UMKM Roti Eyang akan diberikan penjelasan mengenai filosofi dari aset, utang, modal, pedapatan dan beban.

3. Pemilik UMKM Roti Eyang akan diberikan penjelasan terkait cara membuat laporan keuangan di Microsoft excel

4. Pemilik UMKM Roti Eyang akan diberikan kesempatan untuk mencoba membuat laporan keuangannya periode berjalan.

5. Setelah pelaksanaan PKM itu kami menerima kritik dan saran dari pihak pelaku UMKM Roti Eyang berupa 
Loyalitas Kreativitas Aldi Masyarakat Kreatif
Program Studi Ekonomi Manajemen Universitas Pamulang Jurnal LOKABMAS Kreatif Vol.02,No.03.Nov 2021

Hal.109-118

Email:jurnalkreatif.manajemen@gmail.com kuesioner yang berisi instrumen pertanyaan.

6. Selanjutnya kami akan memantau secara berkala atau pendampingan mengenai penerapan Laporan Keuangan pada UMKM Roti Eyang selama beberapa bulan.

\section{HASIL DAN PEMBAHASAN}

Kegiatan PKM ini dilaksanakan pada hari Sabtu, 24 April 2021 yang dihadiri oleh lima peserta, yaitu dari Universitas Pamulang dihadiri oleh tim dosen akuntansi, Putri Nurmala, S.E., M.Si., Akhmad Sigit Adiwibowo, S.E., M.Ak., dan Fina Ratnasari, S.E., M.Ak., selain itu dihadiri pula oleh dosen akuntansi ITB Swadharma, Rita, S.E., M.Ak.., dari UMKM Roti Eyang diwakili oleh pemiliknya, yaitu Bapak Suharso Sulistyo. Kegiatan ini dipandu oleh Ibu Fina Ratnasari, S.E., M.Ak. selaku MC. Sedangkan, pemaparan materi disampaikan oleh Bapak Akhmad Sigit Adiwibowo, S.E., M.Ak.

Materi yang disampaikan mengenai dasar-dasar akuntansi, persamaan akuntansi, filosfi aset, filosfi utang, filosfi modal, filosofi pendapatan dan filosofi biaya. Setelah peserta memahami akuntansi dasar narasumber selanjutnya menjelaskan tetang pentingnya laporan keuangan bagi UMKM dan dilanjutkan praktik pembuatan laporan keuangan menggunakan excel.

Pak Suharso Sulistyo selaku pihak UMKM Roti Eyang mendengarkan materi yang diberikan dengan antusias. Hal itu tercermin ketika kami memaparkan materi dan interaksi yang terjadi antara kami dengan beliau. Beberapa pertanyaan juga terlontar dari Pak Suharso Sulistyo terkait materi yang diberikan.

\section{KESIMPULAN DAN SARAN Kesimpulan}

Berdasarkan hasil kegiatan pelaksanaan pengabdian kepada masyarakat (PKM) yang dilaksanakan oleh tim dosen Prodi Akuntansi Fakultas Ekonomi Universitas Pamulang dapat disimpulkan bahwa kegiatan sosialisasi melalui pemaparan Materi yang disampaikan mengenai dasar-dasar akuntansi, persamaan akuntansi, filosfi aset, filosfi utang, filosfi modal, filosofi pendapatan dan filosofi biaya. Setelah peserta memahami akuntansi dasar narasumber selanjutnya menjelaskan tetang pentingnya laporan keuangan bagi UMKM dan dilanjutkan praktik pembuatan laporan keuangan menggunakan excel. Terlihat semua peserta sangat antusias mengikuti acara sosialisasi pemaparan materi sampai selesai dan peserta dapat memahami dan merasakan manfaat soasialisasi materi tersebut.

\section{Saran}

Ketika kegiatan pengabdian kepada masyarakat ini dapat dilaksanakan, kami berharap para

peserta pelatihan ini merasakan benefit yang sangat besar. Hal ini dikarenakan para peserta memperoleh banyak pengetahuan dan praktik mengenai penyusunan laporan keuangan sederhana bagi pengusaha kecil dan menengah.

Koordinasi dan kerjasama yang dilakukan antara dosen Unpam dalam hal ini pelaksana kegiatan pengabdian masyarakat dengan UMKM diharapkan akan sangat baik. Pihak UMKM frozen food Indonesia sangat menyambut dengan baik kegiatan yang dapat meningkatkan kemampuan para pelaku UMKM.

Pelaksanaan kegiatan pengabdian kepada masyarakat dengan melakukan sosialisasi melalui pemaparan materi yang sama dapat dilaksanakan kembali dengan peserta (audience) yang lebih banyak dan lebih luas serta dengan tambahan topik lainnya serta dapat dilaksanakan secara offline setelah pandemi Covid-19 berakhir, sehingga pencapaian hasil yang diharapkan lebih bisa lebih maksimal.

\section{DAFTAR PUSTAKA}

Achmad Tjahjono, dkk. 2009. Akuntansi Pengantar Pendekatan Terpadu. Unit Penerbit dan Percetakan Akademi Manajemen YKPN. Yogyakarta.

Baridwan, Z. (1997). Analisis Nilai Tambah Informasi Laporan Arus Kas. Jurnal Ekonomi dan Bisnis Indonesia: Vol.12, No.2, 1-17. 
Loyalitas Kreativitas Aldi Masyarakat Kreatif
P-ISSN 2722-2101, E-ISSN 2722-4201

Program Studi Ekonomi Manajemen Universitas Pamulang Jurnal LOKABMAS Kreatif Vol.02,No.03.Nov 2021

Hal.109-118

Email:jurnalkreatif.manajemen@gmail.com
Endarwaty, D. (2009). Sistem Informasi Akuntansi Arus Kas (Studi Kasus Pada SMA Pangudi Luhur Van LithMuntilan). Skripsi. Jurusan Teknik Informatika, Fakultas Sains dan Teknologi, Universitas Sanata Dharma.Yogyakarta.

Harahap, Sofyan Syafri. 2013. Analisa Kritis atas Laporan Keuangan. Jakarta: PT Raja Grafindo Persada.

Husein, Umar. (2000). Riset Pemasaran Dan Penilaian Konsumen. Jakarta: PT Gramedia Pustaka.

Ikatan Akuntan Indonesia. (2018). Standar Akuntansi Keuangan Entitas Mikro, Kecil, dan Menengah (SAK EMKM). Ikatan Akuntansi Indonesia: Jakarta.

Ikatan Akuntansi Indonesia. (2009). Standar Akuntansi Keuangan. Jakarta: Salemba Empat.

Keluarga Pada Ibu-ibu PKK Citra Villa. LOYALITAS, Jurnal Pengabdian Kepada Masyarakat, [S.1.], v. 3, n.2, p. 198-208.

Munawir, S. 2010. Analisis laporan Keuangan Edisi keempat. Cetakan Kelima Belas. Yogyakarta: Liberty

Nurmala, P. \& Adiwibowo, A.S. (2020). Peningkatan Good Governance Melalui Penerapan Kaizen.ABDIMISI, Vol.2 No.1, hal. 50-56.

Nurmala, P. (2014). Analisis Pendidikan Pemilik, Pehamahaman Akuntansi, Budaya Perusahaan, Modal Usaha, dan Umur Usaha Terhadap Penggunaan Informasi Akuntansi Pada Usaha Menengah di Kabupaten Banyumas. Skripsi. Universitas Jenderal Soedirman.

Nurmala, Putri et al. (2020). Pemberdayaan Masyarakat Melalui Pembuatan Laporan Keuangan Sederhana

Pasaribu, V. L. D., Agrasadya, A., Shabrina, N., \& Krisnaldy, K. (2020). Menjadi Enterpreneur Muda Yang Memiliki Jiwa Leadership Untuk Menghadapi Masa Depan. Abdi Laksana: Jurnal Pengabdian Kepada Masyarakat, 1(1).

Pasaribu, V. L. D., Susanti, F., \& Hartuti, E. T. K. (2019). Memotivasi Siswa dan Siswi SMK Letris Indonesia di Dalam Menentukan Pilihan Untuk Melanjutkan Pendidikan Atau Bekerja
Setelah Lulus Sekolah. Jurnal Pengabdian Dharma Laksana, 1(2), 161-172.

Pasaribu, V. L. D., Sulaiman, S., Sutiman, S., Thaharudin, T., \& Purnomo, B. Y. (2020). Pengenalan Letak Posyandu Terdekat Dikelurahan Pisangan Dengan Manajemen Pemasaran Revolusi 4.0 Untuk Meningkatkan Pengetahuan Masyarakat Letak Dan Fungsi Posyandu Terdekat Pada Kelurahan Pisangan. Dedikasi Pkm, 1(1), 105-110.

Pasaribu, V. L. D., Oktrima, B., Prabowo, B., Arianto, N., \& Haryoko, U. B. (2020). Progam Pendampingan Dan Penyelenggaraan Pendidikan Anak Pada Usia Dini Terhadap Prestasi Belajar Dilingkungan Rt $020 \mathrm{Rw} 009$. Kel Giri Peni. Kec Wates. Yogyakarta. Jurnal Lokabmas Kreatif, 1(1), 71-75.

Pasaribu, V. L. D., Jannah, M., Fazar, M., Putra, S. P., Monalisa, M., \& Sofa, M. (2021). MENINGKATKAN

PRODUKTIVITAS USAHA DIMASA PANDEMI PADA IBU PKK RT 004/003 KELURAHAN SAWAH BARU CIPUTAT, TANGERANG SELATAN. Abdi Laksana: Jurnal Pengabdian Kepada Masyarakat, 2(2), 295-301

Pasaribu, V. L. D., Yuniati, H. L., Pranata, R., Sembayu, R., Purba, S. M., \& Nurbayani, T. T. A. (2021). MANAJEMEN KEUANGAN UNTUK MENGHADAPI DAN BERTAHAN DI ERA COVID 19. Jurnal Abdimas Tri Dharma Manajemen, 2(2), 12-18.

Pasaribu, V. L. D., Dwiyatni, A., Sabina, C., Ridwan, M., Gunawan, D. D., \& Noviani, B. C. (2021). EVALUASI PENERAPAN 3M DIMASA PANDEMIC COVID 19. Jurnal Abdimas Tri Dharma Manajemen, 2(2), 54-60.

Pasaribu, V. L. D., Syafei, A. N., Farhan, A., Aufaizah, A., Irani, C., \& Firtiayani, S. R. (2021). PENGARUH DISPLIN PROTOKOL KESEHATAN TERHADAP PENCEGAHAN PENULARAN VIRUS COVID19. Jurnal Abdimas Tri Dharma Manajemen, 2(2), 91-98.

Pasaribu, V. L. D., Septiani, F., Rahayu, S., Lismiatun, L., Arief, M., Juanda, A., ... \& Rahim, R. (2021). Forecast Analysis of Gross Regional Domestic Product based on the 
Loyalitas Kreativitas

Aldi Masyarakat Kreatif
P-ISSN 2722-2101, E-ISSN 2722-4201

Program Studi Ekonomi Manajemen Universitas Pamulang Jurnal LOKABMAS Kreatif Vol.02,No.03.Nov 2021

Hal.109-118

Email:jurnalkreatif.manajemen@gmail.com
Linear Regression Algorithm Technique.

Pasaribu, V. L. D., Priadi, A., Anismadiyah, V., Rahayu, S., \& Maduningtias, L. (2021). PENYULUHAN KREATIF DAN INOVATIF MENINGKATKAN MUTU PRODUKSI UMKM DI DESA BELEGA KABUPATEN GIANYAR. Pro Bono Jurnal Pengabdian Kepada Masyarakat, 1(02).

Pasaribu, V. L. D. (2021). PELATIHAN BERBASIS ONLINE DI ERA COVID-19. Jurnal Abdimas Tri Dharma Manajemen, 2(3), 26-32.

Pasaribu, V. L. D., \& Setyowati, R. (2021). ADAPTASI KEHIDUPAN NEW NORMAL PADA MASA PANDEMI COVID-19 DIYAYASAN PONDOK PESANTREN DAN PANTI ASUHAN NURUL IKHSAN KECAMATAN SETU, KOTA TANGERANG SELATAN. Jurnal Lokabmas Kreatif: Loyalitas Kreatifitas Abdi Masyarakat Kreatif, 2(2), 82-88.

Priadi, A., Pasaribu, V. L. D., Virby, S., Sairin, S., \& Wardani, W. G. (2020). Penguatan Ekonomi Kreatif Berbasis Sumber Daya Desa Dikelurahan Rempoa. Abdi Laksana: Jurnal Pengabdian Kepada Masyarakat, 1(3), 356-35

Pithaloka, D. Nina. (2009). Pengaruh FaktorFaktor Intern Perusahaan terhadap Kebijakan Hutang : Dengan Pendekatan Pecking Order Theory. Skripsi. Bandar Lampung : Universitas Lampung.

Rudianto (2009). Pengantar akuntansi. Jakarta: Penerbit Erlangga.

Rudjito. 2003. Strategi Pengembangan Umkm Berbasis Strategi Bisnis,

Makalah Yang Di Sampaikan Pada Seminar Peran Perbankan Dalam Memperkokoh Ketahanan Nasional Kerjasama Lemhanas RI Dengan BRI

Suadi, A. (1998). Penelitian Tentang Manfaat Laporan Arus Kas. Jurnal Ekonomi dan Bisnis Indonesia: Vol.13, No.2, 1-9.

Undang-Undang N0. 20 tahun 2008 tentang "usaha mikro, kecil dan menengah"
Warren, James, Fess, dkk. 2015. Pengantar Akuntansi. Jakarta: Salemba Empat.

\section{DOKUMENTASI KEGIATAN}
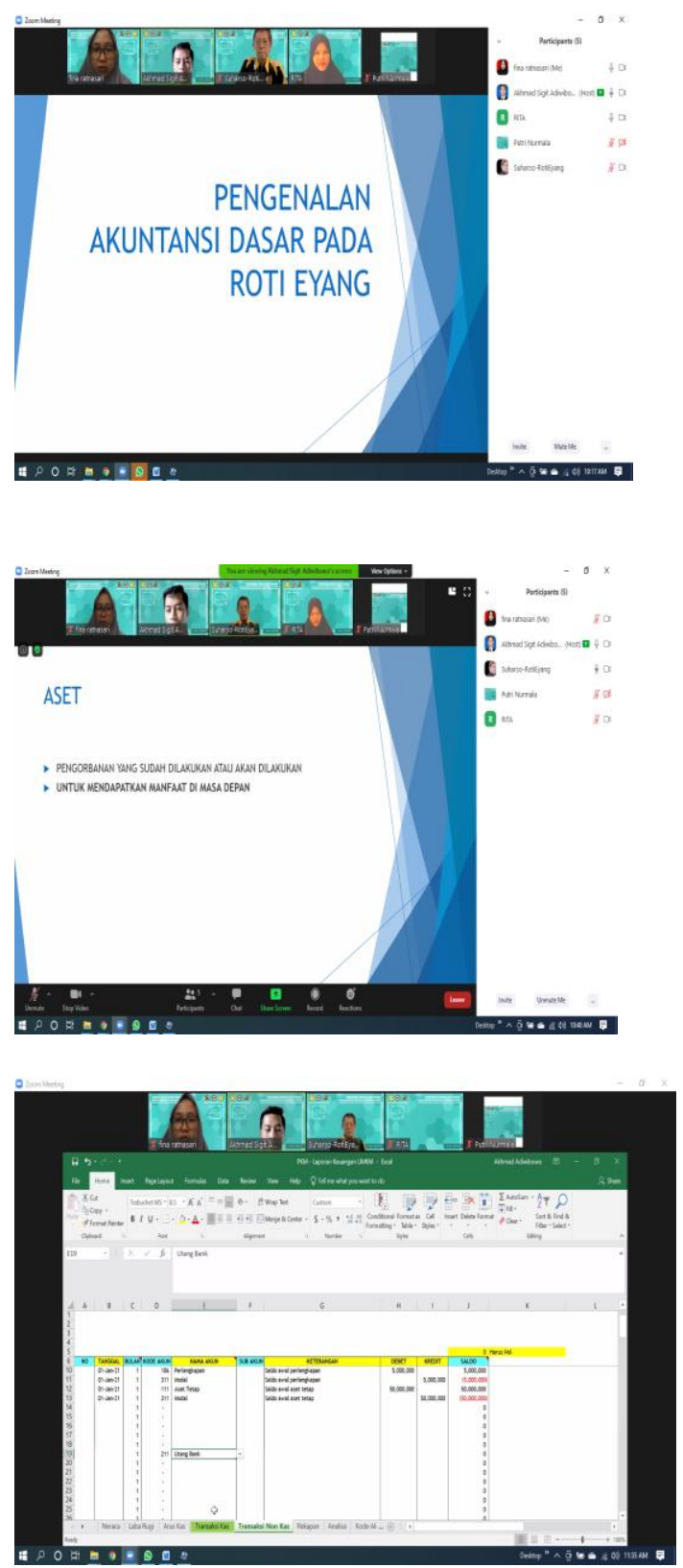
P-ISSN 2722-2101, E-ISSN 2722-4201

Layalitas Kreativitas Program Studi Ekonomi Manajemen Universitas Pamulang Jurnal LOKABMAS Kreatif Vol.02,No.03.Nov 2021

Aldi Masyarakat Kreatif

Hal.109-118

Email:jurnalkreatif.manajemen@gmail.com
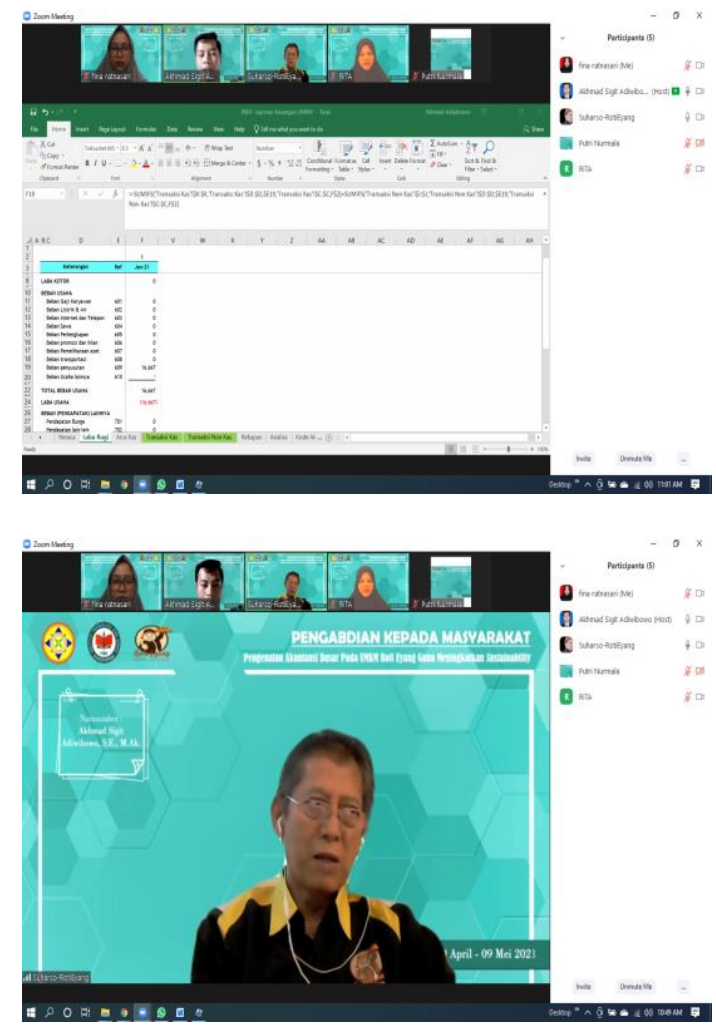